\title{
Analysis Price, Perception of Quality, and Promotion with Intervening Brand Trust Toward Purchase Intention Honda Vario 150CC (Case Study at PT Wahana Makmur Sejati)
}

\author{
Rudy Tanjung Herlambang ${ }^{1}$, Humannisa Rubina Lestari ${ }^{2}$, Dr. Sri Hartono, $\mathrm{MM}^{3}$ \\ Student of Faculty of Economics and Business Postgraduate Studies of MercuBuana University ${ }^{1}$,Student of Faculty of Economics \\ and Business Postgraduate Studies of MercuBuana University ${ }^{2}$, Lecturer of Faculty of Economics and Business Postgraduate \\ Studies of MercuBuana University ${ }^{3}$
}

\begin{abstract}
This research was conducted to analyze the effect of Price, Perceived Quality, and Promotion on Purchase Intention on Honda Vario150CC products with Intervening Brand Trust at PT Wahawa Makmur Sejati. The data used in this study is questionnaire data taken from 200 respondents using convenience sampling. Meanwhile, the data analysis was performed using quantitative statistics using Structural Equation Modeling (SEM) assisted by LISREL version 9.2 software. The results showed that Price, Perceiveds of Quality and Promotion had a significant effect on Brand Trust, and also Brand Trust had a significant effect on Consumer Purchase Intention. In the research results, the direct and indirect relationship, both Price, Perceived of Quality and Promotion, directly have a significant effect on the purchase intention of Vario150CC. However, the variable Price and Perceived Quality indirectly through Brand Trust does not have a significant effect on consumer Purchase Intention. The results of this research can be used as a reference both academically and practically in implementation management by PT WAHANA MAKMUR SEJATI.
\end{abstract}

Keywords:- Price, Perceived Quality, Promotion, Brand Trust, Purchase Intention.

\section{INTRODUCTION}

\begin{abstract}
$>$ Background
The growth of transportation in the era of globalization is increasingly considered important to support the speed of human activity which is always dynamic and fast. Many people in Indonesia choose to use motorbike transportation compared to using other transportation such as cars or other public transportation. According to AISI (Indonesian Motorcycle Industry Association, the growth of the motorcycle business in Indonesia is filled with several leading brands that are competing fiercely to fill the market in Indonesia. Several brands such as Honda, Yamaha, Suzuki, and Kawasaki and several other brands. Each brand has its own characteristics. In reaching the target market, the data reported by the Indonesian Motorcycle Association (AISI) shows that the number of motorbikes that were successfully distributed in 2018 to consumers reached 6,388,191 units.
\end{abstract}

\begin{tabular}{|c|c|c|c|c|}
\hline \multirow{2}{*}{ Sales Brand } & $\mathbf{2 0 1 5}$ & $\mathbf{2 0 1 6}$ & $\mathbf{2 0 1 7}$ & $\mathbf{2 0 1 8}$ \\
\cline { 2 - 5 } & unit & unit & unit & unit \\
\hline Honda & 4.453 .888 & 4.380 .888 & 4.385 .147 & 4.759 .202 \\
\hline Yamaha & 1.798 .630 & 1.394 .078 & 1.347 .918 & 1.456 .088 \\
\hline Suzuki & 109.882 & 56.824 & 72.988 & 89.508 \\
\hline Others & 117.755 & 99.495 & 80.051 & 83.393 \\
\hline Total & 6.489 .155 & 5.931 .285 & 5.886 .103 & 6.388 .191 \\
\hline
\end{tabular}

Table 1:- PenjualanSepeda Motor di Indonesia

The high sales of Honda motorcycles in Indonesia illustrate the consumer brand trust of motorbike users who prefer Honda motorbikes to be reliable enough. Honda Motorcycles are a brand under the auspices of PT. Astra Honda Motor as ATPM as a manufacturer, and in collaboration with PT Wahana Makmur Sejati, which is the only official main dealer for Honda Motorcycles from PT AHM to market Honda motorcycle products in Jakarta Tangerang, where one of the strategies focuses on developing product innovation and improving service quality, is expected to influence and arouse the desire to buy Honda motorbike products.

The data share of Honda motorcycle based on models at PT Wahana Makmur Sejati shows the domination of sales of automatic motorbikes by $92 \%$ in 2018 . In this case, it can be seen that Honda's automatic motorbikes are the main backbone of motorcycle sales in Jakarta, Tangerang. Due to the trend of consumers who tend to choose modern automatic motorbikes compared to conventional 
motorbikes because modern automatic motorbikes have more practicality in driving, better comfort levels, efficient fuel consumption and are considered fashionable in everyday use.

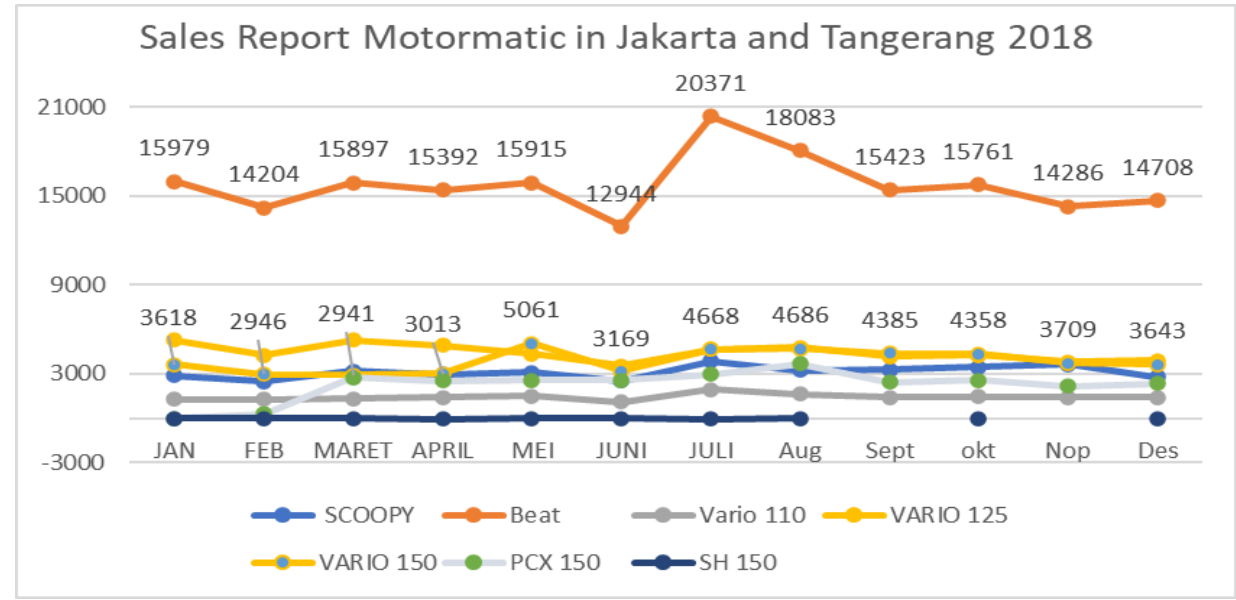

Fig 1:- Sales of Automatic Motorbikes in Jakarta Tangerang 2018

Source: PT Wahana Makmur Sejati's Marketing Data (2018)

From Figure 1, Sales of Honda Matic are dominated by Beat type in the first place than a second-place by Vario 125. In the third rank, Vario 150CC is followed by Scoopy, PCX 150CC, Vario 110, SH 150CC. Vario 150CC of the year 2018 shows that sales continue to decline, while when viewed from the product technology the Vario $150 \mathrm{CC}$ has the same technology that the PCX 150CC has in the premium class, such as automatic ISS (Ignition Stop System), enhancing motorcycle safety such as a safety ignition key (Secure Shut Shutter), Anti Brake Stop System (ABS).

The sales data in Figure 1, Vario 150CC has not been able to attract consumer buying interest, from the mid-year data, it can be seen that there is a decline in sales until the end of the year. For this reason, researchers feel the need to conduct further analysis regarding the decline in sales experienced. The company management needs to analyze the things that affect the buying interest of the $150 \mathrm{CC}$ Vario motorbike which will determine the ups and downs of sales so that there are a balance and an increase in sales. The Vario 150CC motorbike that is favored by the company is still unable to compete with Beat motorbike products which are the favorite choice of Honda motorbike users, even though in terms of specifications the Vario $150 \mathrm{CC}$ is still superior in terms of engines or accessories compared to Beat motorbikes or other Honda motorbikes.

Therefore, in this study, the researcher wanted to analyze the factors that influenced the increase in buying interest. To find out the factors that caused the decrease in the sales volume of the Honda Vario 150, it is necessary to conduct a pre-survey involving 60 respondents, From preliminary observations, it can be concluded that the price factor, the Perceived of a product's quality, and promotion are of particular concern to respondents in assessing a product.

\section{THEORETICAL REVIEW}

Stanton in Sunyoto (2014) price is the value referred to in rupiah and cents or other monetary media as a medium of exchange. While Kotler and Keller (2014) suggest that price is one element of the marketing mix that generates revenue costs. The definition of the price according to Keller and Armstrong (2017) is "price is the amount of money charged for a product or service," which means the amount of money charged for a product or service. PT Wahana Makmur Sejati has a variety of prices according to the specifications of the motorbike and also the target segmentation.

According to Hawkins and Mothersbough (2013), "price is the amount of money one must pay to obtain the right to use the product," or it means that price is the amount of money that must be paid to obtain the right to use a product. Price is perhaps the easiest element in a marketing program to customize, while product features, channels, and even communications take more time to adjust.

Sunyoto (2014) fixing prices, among others, is an effort not to take actions that increase profits when the company is experiencing unfavorable market conditions. Next, to maximize profit, pricing aims to maximize profit within a certain period. Furthermore, to maximize sales, which aims to build market share by selling at a disadvantageous initial price. Another goal of prestige, the purpose of price is to position the company's services as an exclusive product. The purpose of pricing is also for the development of investment (ROI). Next, the objective of determining the price based on achieving the desired return on investment. According to Suwarni in Rarun (2013: 1113) states that the price is the amount of money set by the company is used to get several physical or non-physical products. Price is one of the factors that must be controlled harmoniously and in line with the goals the company wants to achieve. 
Perceived is the process used by individuals to select, organize, and interpret input information to create meaningful images. Whereas quality is a combination of traits and characteristics that determine the extent to which output can meet the requirements of consumer needs or an assessment of how far these characteristics and characteristics meet various needs (Tjiptono, 2008).

Beneke (2013) defines the Perceived of product quality as the way consumers view the brand equity of a product and its overall advantage compared to other available alternatives. This is related to consumer attitudes towards the experience of a particular brand as a whole.

Thus the Perceived of quality is formed because of the active relationship between marketers and consumers. Furthermore, consumers will use product performance, product conformity with manufacturing standards, and product-specific attributes to assess product quality. Perceived quality is a consumer's assessment of the overall superiority of the product, not the actual quality of the product itself. therefore the Perceived of quality cannot be objectively determined. In addition, consumers have a tendency to perceive subjectively by involving everything they think is important, because each consumer has different interests in a product or service.

Promotion is one of the variables in the marketing mix which is very important for companies to implement in marketing their products or services. Sometimes the term promotion is used synonymously with the term sales even though it is a promotion. The definition of promotion by Kotler and Armstrong (2017), is designed as attractive as possible to reach the community through various media, so companies can communicate with consumers.

Trust is a key mediator for long-term relationships that lead to brand loyalty. Trust has a technical nature and can be created. Technical properties refer to the meeting between expectations and fulfillment of customer needs, while customizable properties refer to consistency in providing the same value across all types of products. The source of the Brand Trust is based on the experience of consumers about a brand. According to research conducted by Huang (2017), sensory experiences have the highest effect on Brand Trust compared to other experiences.

Consumers who already have a positive attitude towards a product or brand will generate interest in purchasing the product or brand. So, it can be concluded that Purchase Intention is the possibility that consumers will purchase by seeking information from various sources. Consumers have an interest in a product or service, but it is not certain that consumers will purchase the product or service. According to Kinnear and Taylor in Edison (2014) Purchase Intention is the stage of the consumer's tendency to act before the buying decision is implemented. There is a difference between actual purchase and Purchase Intention. If an actual purchase is a purchase that is made by a consumer, then purchase intention is the intention to purchase a future opportunity. In line with Ferdinand
(2015) Purchase Intention is the tendency of consumers to buy a brand or take actions related to purchases as measured by the level of consumers' likelihood of making a purchase.

\section{RESEARCH METHODS}

\section{$>\quad$ Type of Research Design}

This research was a quantitative study that can be determined by only a few variables of the object under study and then can make an instrument to measure it (Sugiyono, 2015). Of this type, this research is field research, which focuses on the results of data collection from informants that have been conducted. Field research is a research conducted directly. The type of research used in this research is quantitative research designed to assist decision makers in determining, evaluating and selecting a series of actions to be taken in certain situations (Malhotra, 2009). The technical analysis used in this research is Structural Equation Modeling (SEM) of LISREL version 9.2 software used in model development and hypothesis testing.

\section{$>\quad$ Research Approach}

The analysis in this study is quantitative since statistics are presented. This is consistent with Arikunto 's view (2006: 12) that quantitative analysis is a method of evaluating numbers typically anticipated beginning at data collection, data analysis, and results from presentation. The quantitative analysis employed a qualitative approach, starting with data collection, interpretation of data and tests. Similarly, if accompanied by tableaux, graphs, maps, pictures and others, interpretation of the results of studies would be more persuasive (Arikunto 2006).

\section{$>\quad$ Population and Research Sample}

The population is a general category of objects or subjects with specific attributes and characteristics to be investigated and then drawn conclusions by researchers. Meanwhile, the population is the entire focus of research, according to Arikunto (2006). The target population in this study is the entire population of Indonesia. While the target market for PT Wahana Makmur Sejati (WMS) is residents living in DKI Jakarta and Tangerang, the study population chosen in this study were residents of DKI Jakarta and Tangerang with vulnerable ages of 21-60 years, totaling $6,957,876$ people. This population study was chosen because the vulnerable at this age are considered to have entered adulthood and can make decisions independently.

The sample size in this study was determined based on the data analysis method to be used. The data analysis method used is the Structural Equation Model (SEM), so the ideal and representative sample size is between 100-200 depending on the number of parameters estimated. The guideline is 5-10 times the number of indicators of all variables following the advice of Hair et al. (2008). Based on these guidelines, the number of samples in this study was 5 x $24=120$ respondents, rounded to 200 respondents. The questionnaire was distributed to respondents and checked beforehand by providing questionnaires to 60 
respondents. This pre-test attempts to assess the reliability and validity of the questionnaires. Researchers have used the LISREL9.2 software. The Google questionnaire was distributed to 200 respondents.

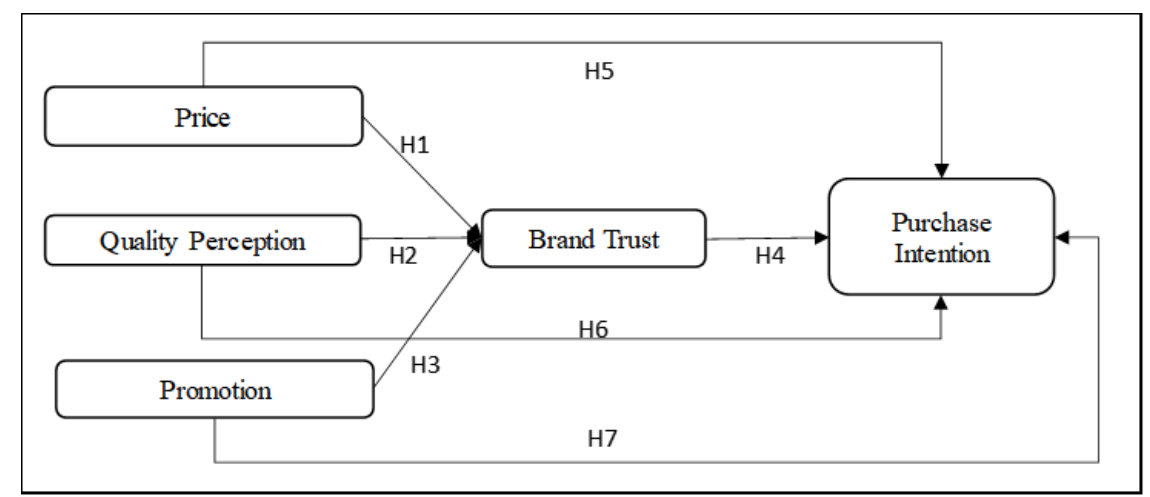

Fig 2:- Research Framework

Source: Primary Data, 2020

$X_{1}=$ Price

$X_{2}=$ Quality Perceived

$X_{3}=$ Promotion

$X=$ Brand Trust (Intervening)

$Y=$ Purchase Intention

\section{RESEARCH RESULTS AND DISCUSSION}

\section{Data Analysis Results}

This research uses LISREL9.2 analysis. The theoretical model that has been described in the path diagram will be analyzed based on the data obtained. Outer Model measurement is testing the relationship between indicators and latent variables. The combination of structural model testing and measurement allows researchers to test measurement error as an inseparable part of LISREL9.2 and conduct factor analysis together with hypothesis testing.

The validity test refers to the measurement instrument, which is to test whether the measurement instrument used can measure the variable to be measured. Measurement instruments or variable indicators are confirmed to have met the validity assumption if the t-value> 1.96 and the standardized loading factor value> 0.5 . The second test measuring instrument (questionnaire) is reliability, which is a tool to measure the consistency of a questionnaire as an indicator of a variable or construct. The method used to calculate the reliability of the instrument is using the construct reliability index. The limit value used to assess the level of reliability was> 0.7. According to Ghozali (2016) the formula used to calculate construct reliability (CR)

\begin{tabular}{|c|c|c|c|c|c|}
\hline \multirow{2}{*}{ Indicator Code } & \multirow{2}{*}{ SLF } & \multirow{2}{*}{ Standard Errors } & \multicolumn{2}{|c|}{ Reliability } & \multirow{2}{*}{ Remark } \\
\cline { 5 - 5 } & & & $\mathbf{C R} \geq \mathbf{0 , 7 0}$ & VE $\geq \mathbf{0 , 5}$ & \\
\hline H1 & 0,86 & 0,27 & \multirow{2}{*}{$\mathbf{0 , 8 9}$} & \multirow{2}{*0,68}{} & Valid \\
\hline H2 & 0,74 & 0,36 & & Valid \\
\hline H3 & 0,87 & 0,25 & & Valid \\
\hline H4 & 0,78 & 0,36 & & Valid \\
\hline
\end{tabular}

Table 2:- Validity and Reliability of Price Variables (X1)

Table 2 shows that there are 4 indicators in the latent variable Price (X1) that have passed the validity test, because of the 4 variable indicators all loading factor values $>0.50$. While the reliability test results of the Price variable (X1) produce good reliability values were the results of the Construct Reliability $(\mathrm{CR})$ value $=0.89>0.7$, and the Variance Extracted (AVE) value of $0.68>0.50$. Thus the latent variable Price $(\mathrm{X} 1)$ has met the validity and reliability test requirements.

\begin{tabular}{|c|c|c|c|c|c|}
\hline \multirow{2}{*}{ Indicator Code } & \multirow{2}{*}{ SLF } & \multirow{2}{*}{ Standard Errors } & \multicolumn{2}{|c|}{ Reliability } & \multirow[b]{2}{*}{ Remark } \\
\hline & & & $\mathrm{CR} \geq 0,70$ & $\mathrm{VE}>0,5$ & \\
\hline PK1 & 0,83 & 0,30 & \multirow{6}{*}{0,96} & \multirow{6}{*}{0,79} & Valid \\
\hline PK2 & 0,88 & 0,19 & & & Valid \\
\hline PK3 & 0,93 & 0,12 & & & Valid \\
\hline PK4 & 0,88 & 0,20 & & & Valid \\
\hline PK5 & 0,87 & 0,18 & & & Valid \\
\hline PK6 & 0,85 & 0,22 & & & Valid \\
\hline
\end{tabular}

Table 3:- Validity and Reliability of Quality Perception Variables (X2) 
Table 3 above shows that there are 6 indicators of observed variables in the quality perception latent variable (X2) that have passed the validity test, because of the 6 variable indicators all loading factor values $>0.50$. While the reliability test results of the Quality Perception variable (X2) produced good reliability values where the results of the Construct Reliability $(\mathrm{CR})$ value = 0.96>0.7 and the Variance Extracted (AVE) value was 0.79>0.50. Thus the quality perception latent variable (X2) has met the validity and reliability test requirements.

\begin{tabular}{|c|c|c|c|c|c|}
\hline \multirow{2}{*}{ Indicator Code } & \multirow{2}{*}{ SLF } & \multirow{2}{*}{ Standard Errors } & \multicolumn{2}{|c|}{ Reliability } & \multirow{2}{*}{ Remark } \\
\hline & & & $\mathrm{CR} \geq \mathbf{0 , 7 0}$ & $\mathrm{VE} \geq 0,5$ & \\
\hline $\mathrm{P} 1$ & 0,88 & 0,22 & \multirow{8}{*}{0,94} & \multirow{8}{*}{0,67} & Valid \\
\hline $\mathrm{P} 2$ & 0,87 & 0,23 & & & Valid \\
\hline $\mathrm{P} 3$ & 0,91 & 0,14 & & & Valid \\
\hline $\mathrm{P} 4$ & 0,83 & 0,29 & & & Valid \\
\hline P5 & 0,79 & 0,32 & & & Valid \\
\hline P6 & 0,88 & 0,17 & & & Valid \\
\hline P7 & 0,61 & 0,67 & & & Valid \\
\hline P8 & 0,64 & 0,59 & & & Valid \\
\hline
\end{tabular}

Table 4:- Validity and Reliability of Promotion Variables (X3)

Table 4, show that there are 8 indicators of observed variables in the latent variable Promotion (X3) that have passed the validity test, because of the 8 variable indicators all loading factor values $>0.50$. While the reliability test results of the Promotion variable $(\mathrm{X} 3)$ produce good reliability values were the results of the Construct Reliability $(\mathrm{CR})=0.94>0.7$, and the Variance Extracted (AVE) value of 0.67> 0.50. Thus the latent variable Promotion (X3) has met the validity and reliability test requirements.

\begin{tabular}{|c|c|c|c|c|c|}
\hline \multirow{2}{*}{ Indicator Code } & \multirow{2}{*}{ SLF } & \multirow{2}{*}{ Standard Errors } & \multicolumn{2}{|c|}{ Reliability } & \multirow{2}{*}{ Remark } \\
\cline { 5 - 5 } & & & CR $\geq \mathbf{0 , 7 0}$ & VE $\geq \mathbf{0 , 5}$ & \\
\hline BT1 & 0,92 & 0,13 & $\mathbf{0 , 9 1}$ & $\mathbf{0 , 8 3}$ & Valid \\
\hline BT2 & 0,87 & 0,19 & & Valid \\
\hline
\end{tabular}

Table 5:- Validity and Reliability of Brand Trust Variables (Z)

Table 5, shows that there are 2 indicators of observed variables in the latent variable Brand Trust (Z) that have passed the validity test, because of the 2 variable indicators all loading factor values $>0.50$. While the reliability test results of the Brand Trust $(Z)$ variable produced good reliability values where the results of the Construct Reliability $(\mathrm{CR})$ value $=0.91>0.7$ and the Variance Extracted (AVE) value was $0.83>0.50$. Thus the latent variable Brand Trust $(\mathrm{Z})$ has met the requirements of the validity and reliability test.

\begin{tabular}{|c|c|c|c|c|c|}
\hline \multirow{2}{*}{ Indicator Code } & \multirow{2}{*}{ SLF } & \multirow{2}{*}{ Standard Errors } & \multicolumn{2}{|c|}{ Reliability } & \multirow{2}{*}{ Remark } \\
\cline { 6 - 6 } & & & $\mathbf{C R} \geq \mathbf{0 , 7 0}$ & VE $\geq \mathbf{0 , 5}$ & \\
\hline MB1 & 0,81 & 0,24 & \multirow{2}{*}{$\mathbf{0 , 8 9}$} & \multirow{2}{*}{$\mathbf{0 , 6 8}$} & Valid \\
\hline MB2 & 0,90 & 0,18 & & Valid \\
\hline MB3 & 0,73 & 0,57 & & Valid \\
\hline MB4 & 0,82 & 0,29 & & Valid \\
\hline
\end{tabular}

Table 6:- Validity and Reliability of Purchase Intention Variables (Y)

Table 6, shows that there are 4 indicators of observed variables in the latent variable of Purchase Interest $(\mathrm{Y})$ that have passed the validity test, because of the 4 variable indicators all loading factor values> 0.50. While the reliability test results of the Purchase Interest (Y) variable produced a good reliability value were the results of the Construct Reliability (CR) value $=0.89>0.7$, and the Variance Extracted (AVE) value of $0.68>0.50$. Thus the latent variable Buying Interest (Y) has met the validity and reliability test requirements.
After calculating and analyzing Confirmatory Factor Analysis (CFA), here is a structural equation model measurement variable to analyze the relationship between suitability and hypotheses on research variables. The overall model fit test conduct to see how well the resulting model describes its actual conditions. Research data processing using the maximum likelihood method on the Lisrel 9.2 application. Based on data processing, structural equation goodness of fit is produced as described in Table 7. 


\begin{tabular}{|l|c|c|c|c|}
\hline \multirow{2}{*}{\multicolumn{1}{|c|}{ Goodnes Of Fit }} & \multicolumn{2}{c|}{ Scale } & \multicolumn{2}{c|}{ Result } \\
\cline { 2 - 5 } & Good Fit & Marginal Fit & \multicolumn{2}{c|}{} \\
\hline Normed Chi-Square $\left(\chi^{2} / \mathrm{df}\right)$ & $<2.0$ & & 2.090 & Not Fit \\
\hline $\begin{array}{l}\text { Root Mean Square Error } \\
\text { (RMSEA) }\end{array}$ & $<0.08$ & & 0.077 & Fit \\
\hline $\begin{array}{l}\text { Root Mean Square Residual } \\
(\text { RMR) }\end{array}$ & $<0.05$ & & 0.044 & Fit \\
\hline Goodness of Fit Index (GFI) & $\geq 0.90$ & $0.70<0.90$ & 0.83 & $\begin{array}{c}\text { Marginal } \\
\text { Fit }\end{array}$ \\
\hline Normal Fit Index (NFI) & $\geq 0.90$ & $0.80-<0.90$ & 0.98 & Fit \\
\hline Non-Normed Fit Index (NNFI) & $\geq 0.90$ & $0.80-<0.90$ & 0.98 & Fit \\
\hline Comparative Fit Index (CFI) & $\geq 0.90$ & $0.80-<0.90$ & 0.99 & Fit \\
\hline Increamental Fit Index (IFI) & $\geq 0.90$ & $0.80-<0.90$ & 0.99 & Fit \\
\hline Relative Fit Index (RFI) & $\geq 0.90$ & $0.80-<0.90$ & 0.97 & Fit \\
\hline
\end{tabular}

Table 7:- Goodness of Fit Full Model

The SEM analysis results illustrate that the GFI value is 0.83 close to 0.90 (marginal fit), the RMSEA value is $0.077<0.08$ (model fit), this shows that the structural equation model meets the absolute fit measure requirements, which means that the structural equation model in this study as a whole has compatibility with the data. In the incremental fit measure requirements, the NNFI / TLI value is $0.98 \geq 0.90$ (fit model), CFI value $0.99 \geq 0.90$ (model fit), RFI value $0.97 \geq 0.90$ (model fit), NFI value 0.98 $\geq 0.90$ (fit model), and IFI $0.99 \geq 0.90$ (model fit), indicating that the structural equation model meets the incremental fit measure requirements, then for the parsimonious fit measure requirement, the normed chi-square value is $2.182<2.0$ (the model is not fit), indicating that 7 out of 9 criteria state the model is fit, with Thus the structural equation model meets the parsimonious fit measure requirements, which means that the overall structural equation model in this study has a comparative fit with the baseline model (null model). Evaluation of Measurement Hypothesis Model in Table 8.

\begin{tabular}{|c|c|c|c|}
\hline Construct Relation & Estimates & T-Values & Remark \\
\hline Price ->Brand Trust & 0,28 & 2,15 & Significant \\
\hline Quality Perceived ->Brand Trust & 0,28 & 2,06 & Significant \\
\hline Promotion ->Brand Trust & 0,41 & 5,18 & Significant \\
\hline Brand Trust ->Purchase Intention & 0,34 & 2,49 & Significant \\
\hline
\end{tabular}

Table 8:- Hypothesis

Source: Results of analysis using LISREL9.2

Hypothesis in this study based on Table 2 is as follows:

- Direct Influence of Price on Brand Trust (Z)

The research hypothesis (H1) states that Price has a positive and significant effect directly on Brand Trust. The SEM test results show that the t-value of 2.15 is greater than 1.96 , and the estimate value is 0.28 or $28.0 \%$ of the effect on Brand Trust. The results of this study also confirm the results of the study Price has a significant effect on Brand Trust. And according to Ghassani (2017), Price has a positive effect on Brand Trust. In other words, if the price has increased, it will affect the increase in Brand Trust. Based on these empirical facts and supported by the results of previous research, it can be concluded that the research hypothesis $(\mathrm{H} 1)$ can be accepted that Price has a positive and significant effect directly on Brand Trust.

\section{- The Effect of Quality Perceptions on Brand Trust (Z) Directly}

The research hypothesis (H2) states that Perception of Quality has a positive and significant direct effect on Brand Trust. The SEM test results show that the t-value 2.06 is greater than 1.96 , and the estimate value is 0.28 or $28.0 \%$ of the effect on Brand Trust. The results of this study also confirm the results of research from Cakmak (2017) which states that good quality perceptions will lead to strong Brand Trust. Based on these empirical facts and supported by the results of previous studies, it can be concluded that the research hypothesis (H2) can be accepted that Perceptions of Quality have a positive and significant effect directly on Brand Trust. 


\section{- Direct Effect of Promotion on Brand Trust (Z)}

The research hypothesis $(\mathrm{H} 3)$ states that Promotion has a positive and significant direct effect on Brand Trust. The results of testing with SEM showed that the t-value of 5.18 was greater than 1.96 , and the estimate value was 0.41 or $41.0 \%$ of the effect on Brand Trust. This study also confirms the results of research by Dharmmesta (2010) which states that promotion mix is the best combination of strategies from advertising, personal selling, and other promotional tools which are all planned to achieve the goals of the sales program. In research conducted by Aryatama (2015), it is stated that promotion has a significant effect on buying interest in products that have a strong Brand Trust. In other words, if the Promotion has increased it will affect the increase in Brand Trust. Based on these empirical facts and supported by the results of previous studies, it can be concluded that the research hypothesis (H3) can be accepted that Promotion has a positive and significant effect directly on Brand Trust.

\section{- The Influence of Brand Trust (Z) on Purchase Intention (Y)}

The research hypothesis (H4) states that Brand Trust has a positive and significant direct effect on Purchase Intention. The results of the SEM test showed that the tvalue of 2.49 was greater than 1.96 , and the estimate value was 0.34 or $34.0 \%$ of the effect on Buying Interest. The results of this study also confirm the results of research by Ika (2011) which states that Brand Trust affects the interest in purchasing Honda motorbike products. Based on these empirical facts and supported by the results of previous studies, it can be concluded that the research hypothesis (H4) can be accepted that Brand Trust has a positive and significant effect directly on Purchase Intention.

\section{Indirect Effect Analysis}

\begin{tabular}{|c|c|c|c|c|}
\hline \multicolumn{2}{|r|}{ Construct Relation } & Estimates & T-Values & Remarks \\
\hline \multirow{3}{*}{ Direct } & Price ->Purchase Intention & 0,29 & 2,25 & Significant \\
\hline & Quality Perception ->Purchase Intention & .04 & 0,30 & Not Significant \\
\hline & Promotion->Purchase Intention & 0,33 & 3,58 & Significant \\
\hline & Brand Trust $->$ Purchase Intention & 0,34 & 2,49 & Significant \\
\hline \multirow{3}{*}{ Indirect } & Price ->Brand Trust ->Purchase Intention & 0,09 & 1,66 & Not Significant \\
\hline & $\begin{array}{c}\text { Quality Perception ->Brand Trust ->Purchase } \\
\text { Intention }\end{array}$ & 0,10 & 1,54 & Not Significant \\
\hline & Promotion-->Brand Trust ->Purchase Intention & 0,14 & 2,29 & Significant \\
\hline
\end{tabular}

Table 9:- Direct and Indirect Effects

Based on Table 3 it can be interpreted as follows:

- There is a significant effect of Price (X1) on Purchase Intention ( $Y$ ) through the Brand Trust $(Z)$ variable

Based on Table 3, it is known that the t-Values value $=1.66<1.96$. The coefficient value is positive, which is 0.09 , which means that the price variable (X1) does not affect the Purchase Intention variable (Y) through the Brand Trust $(\mathrm{Z})$ variable. Thus the hypothesis $\mathrm{H} 5 \mathrm{~b}$ indirect effect in this study which states that "Price (X1) has a significant effect on Purchase Intention (Y) through Brand Trust" is rejected.

- There is a significant effect on perceived quality (X2) on buying interest $(Y)$ through the Brand Trust (Z) variable.

Based on Table 3, it is known that the value of tValues $=1.54$ which is smaller than $\mathrm{t}=1.96$ The coefficient value is positive, which is 0.1 , which means that the perceived quality variable (X2) has no effect on the Purchase Intention (Y) variable through the Brand variable. Trust (Z). Thus the hypothesis of the indirect effect of H6b in this study which states that "Perception of Quality (X2) has a significant effect on Purchase Intention (Y) through Brand Trust" is rejected.
- There is a significant effect of Promotion (X3) on Purchase Intention ( $Y$ ) through the Brand Trust (Z) variable

Based on Table 3, it is known that the value of tValues $=2.29>1.96$. The coefficient value is positive, namely 0.14 , which means that the Promotion variable (X3) has a positive effect on the Purchase Intention variable (Y) through the Brand Trust $(\mathrm{Z})$ variable by $14 \%$. Thus the hypothesis $\mathrm{H} 7 \mathrm{~b}$ indirect effect in this study which states that "Promotion (X3) has a significant effect on Purchase Intention (Y) through Brand Trust" is accepted.

- There is a significant effect of Price (X1) on Purchase Intention $(Y)$

Based on Table 3, it is known that the value of tValues $=2.25>1.96$. The coefficient value is positive, which is 0.29 , which means that the price variable (X1) has a positive effect on the Purchase Intention variable (Y) by 29\%. Thus the hypothesis H5a in this study which states that "Price (X1) has a significant effect on Purchase Intention (Y) is accepted. 
- There is a significant effect on perceived quality (X2) on buying interest $(Y)$

Based on Table 3, it is known that the value of $\mathrm{t}$ Values $=0.3$ which is smaller than $t=1.96$. The coefficient value is positive, which is 0.04 , which means that the perceived quality variable (X2) does not affect the Purchase Intention variable (Y). Thus the hypothesis H6a in this study which states that "Perception of Quality (X2) has a significant effect on Purchase Intention (Y)" is rejected.

\section{- There is a significant effect of Promotion (X3) on Purchase Intention ( $Y$ )}

Based on Table 3, it is known that the value of tValues $=3.58>1.96$. The coefficient value is positive, which is 0.33 , which means the Promotion variable (X3) has a positive effect on the Purchase Intention variable (Y) by $33 \%$. Thus the hypothesis H7a in this study which states that "Promotion (X3) has a significant effect on Buying Interest $(\mathrm{Y})$ " is accepted.

\section{CONCLUSION}

The price variable has a positive and significant effect on Brand Trust by $28 \%$. Managerial Implications that must be done by the company, namely by designing a reasonable price in accordance with the performance and value of the motor offered. The higher the price of an item as proven by its equivalent quality will increase the Brand Trust towards the brand.

$>$ The perceived quality variable has a positive and significant effect on Brand Trust by $28 \%$. Managerial Implications that must be done by the company, namely by improving product quality and providing reliable product warranty guarantees. The better the perception of the quality of a product will increase the Brand Trust towards the brand.

$>$ The promotion variable has a positive and significant effect on Brand Trust at 41\%. Managerial Implications that must be carried out by the company, namely by increasing more creative and intense promotion through existing promotional media. The more event promotions carried out by the dealer, the more Brand Trust will increase the brand.

The Brand Trust variable has a positive and significant effect on Purchase Intention by $34 \%$. Managerial Implications must be carried out by the company, namely by meeting consumer expectations, especially consistent in maintaining reliability, comfort, and quality of the product. The higher the Brand Trust of a product, the more consumers buy the Vario 150CC.

$>$ The price variable directly has a positive and significant effect on Purchase Intention by $29 \%$. Managerial Implications that must be done by the company are by making attractive discount promos such as special discounts for civil servant and teacher buyers. Or special discount discounts on special events such as holidays, religious holidays. The more reasonableness the price given by the dealer will generate interest in buying the Vario 150CC product because it is considered a product of equal quality.
The price variable indirectly has a negative and significant effect on Purchase Intention through Brand Trust by $9 \%$ with a T-value of only 1.66 . This shows that Price will determine a higher effect on interest. Managerial Implications that must be done by the company, namely by not giving excessive price discounts on mainstay products in order to achieve sales targets.

$>$ The perceived quality variable has no direct effect on buying interest, it only shows $4 \%$. The company does not need to improve the perception of quality, more focus on other factors that are more influential. The better the quality perception of the Vario 150CC product will increase consumer Purchase Intention to choose the Vario as the first choice for Honda automatic motorbikes.

$>$ The perceived quality variable indirectly has no effect on buying interest through Brand Trust, it only shows $10 \%$, although the effect is greater than directly, the Tvalue shows the number 1.54 which is still not in accordance with the minimum $\mathrm{T}$-value of 1.96. The company focuses on other variables that have a big influence.

$>$ The promotion variable directly has a positive and significant effect on Purchase Intention by $33 \%$. Managerial Implications that must be done by the company, namely by making an attractive promotion, through the theme and appearance of the product advertisement star according to the product positioning segment will be targeted. The increasing number of event promotions both in interactive marketing will increase consumer buying interest to choose the Vario $150 \mathrm{CC}$ as the choice.

The promotion variable directly has a positive and significant effect on Buying Interest through Brand Trust by $14 \%$. Managerial Implications that must be done by the company, namely increasing direct interactive promotions to increase buying interest such as promoting DP on national holidays and others.

\section{REFERENCES}

[1]. Arikunto, S. 2013. Prosedur Penelitian: Suatu Pendekatan Praktik. Rineka Cipta. Jakarta.

[2]. Aryatama, Nicko Bintang dan Mustofa Kamal.2015. Analisis Pengaruh Promosi, Kualitas Produk, dan Layanan Purna jual terhadap Minat Beli Motor Yamaha.Diponegoro Journal of Management Vol 4 No 1 tahun 2015:1 ISSN (online):2337-3792

[3]. Beneke, Justin., Ryan Flynn., Tamsin Greig dan Melissa Mukaiwa. 2013. The influence of perceived product quality, relative price and risk on customer value and willingness to buy: a study of private label merchandise. Journal of Product and Brand Management. Vol. 22, No. 3. Hal. 218-228.

[4]. Cakmak, I. 2016. The role of brand awareness on brand image, perceived quality and effect on risk in create brand trust. Global Journal on Humanities and Social Sciences, 4, 177-186 
[5]. Dharmmesta, Basu Swastha dan T. Hani Handoko. 2012. Manajemen Pemasaran Analisis Perilaku Konsumen. Edisi Pertama. BPPFE.Yogyakarta

[6]. Edison dan Sri Astuti. 2014. Pengaruh Persepsi Kualitas dan Persepsi Harga terhadap Perceived Value, Citra Perusahaan dan Minat konsumen Membeli Beras Bulog di Kota Pekanbaru. Jurnal Tepak Manajemen Bisnis. Vol. VI, No. 2. Hal 20-30.

[7]. Ferdinand, Augusty. 2015. Structural Equation Modeling dalam Penelitian Manajemen Aplikasi Model-Model Rumit dalam Penelitian untuk Tesis Magister dan Disertasi Doktor. Badan Penerbit Universitas Diponegoro. Semarang.

[8]. Ghassani, M. T. (2017). Pengaruh Kualitas Produk dan Harga Terhadap Minat Beli Ulang Bandeng Juwana Vaccum Melalui Kepuasan Konsumen Sebagai Variabel Intervening (Studi Kasus Pada Pelanggan PT. Bandeng Juwana Elrina Semarang). Diponegoro Journal of Social and Political Science, 18.

[9]. Ghozali, Imam. 2016. Aplikasi Analisis Multivariete Dengan Program IBM SPSS 23 (Edisi 8). Cetakan ke VIII. Badan Penerbit Universitas Diponegoro.Semarang.

[10]. Hawkins, Del I. dan Mothersbaugh,david L. 2013. Consumer Behaviour : Building Marketing Strategy. USA : McGraw-Hills.

[11]. Huang, C. C. 2017. The impacts of brand experiences on brand loyalty: mediators of brand love and trust. Management Decision, 55(5), 915-934. https://doi.org/10.1108/MD-10- 2015-0465

[12]. Ika,Nuruni dan Kustini.2011. Experiential Marketing Emotional, Branding and Brand Trust and Their Effect on Honda Motorcycle Product. Journal of Economics, Business and Accountancy Ventura Volume 14, No. 1, April 2011, pages 19 - 28. Accreditation No. 110/DIKTI/Kep/2009

[13]. Kotler dan Keller.2014.Manajemen Pemasaran.Edisi 12.Erlangga.Jakarta

[14]. Kotler, Philip dan Gary Armstrong. 2017. Priciples of Marketing $15^{\text {th }}$ Ed.Pearson.Boston.

[15]. Malhotra, Naresh K. 2009. Riset Pemasaran: Pendekatan Terapan. Jilid 1. Indeks. Jakarta.

[16]. Rarun, Wandy. 2013. Persepsi Kualitas, Persepsi Nilai, dan Niat Pembelian Terhadap Harga telepon Genggam Samsung Pada PT. Megamitra makmur Sejahtera. Jurnal EMBA. Vol. 4, No. 3, Hal 11111119.

[17]. Sunyoto, D. 2013. Teori, Kuisioner dan Analisis Data.Graha Ilmu. Yogyakarta.

[18]. Tjiptono, Fandy. 2008. Strategi Pemasaran. Andi. Yogyakarta.

[19]. Triptodjojo, Kartika Imasari. 2012. Odd Price: Harga, Psikologi Dan Perilaku Konsumen Dalam Purchase Decision Making.Jurnal manajemen. Vol. 11, No. 2. Hal 141-150 